\title{
DAILY-Life OBJECTS OF THE "OThers" IN THE NEW Kingdom Military SourCES
}

\section{Ahmad Abo el Magd \\ Faculty of TOURISM ANd Hotels, Minia University, Egypt}

\section{Abstract}

This paper discusses the daily-life objects of the others, i.e. the foreign enemies of Egypt and more specifically the Asiatics, Tjemehu-Libyans and Nubians. These daily-life objects like furniture, jewellery, plates, razors, clothes, etc. were mentioned or depicted in the New Kingdom textual and pictorial sources in the context of recording narratives of the wars as occurred in the Annals of King Thutmose III at Karnak or the scenes of booty of wars presentation to god Amun and his Triad after the royal victorious return loaded with objects he captured from his defeated enemies in the battlefield, after the destruction of their camp or their City Assault.

The present research argued that these daily-life objects can be considered as a clear and strong indication to the contemporaneous Ancient Near East, Libyan and Nubian cultures.

KeYwORDS: Foreign Civil Items, New Kingdom, Textual Sources, Pictorial Sources.

\section{INTRODUCTION}

Isolated by deserts, cataracts, and seas, for the first 1500 years of its recorded history the Egyptian Nile Valley was effectively protected against major foreign incursions. On the other hand, Egypt did have active international relations. Egyptian expeditions, mainly to Lower Nubia and Phoenician Coast, with superior manpower, weaponry, and organization, felt free to exploit the greater world at will in the quest for needed raw materials and luxury trade goods. Sometimes more distant contacts, probably on more equal terms were maintained with African Punt and the Egyptianized port city of Byblos in Syria. ${ }^{1}$

\footnotetext{
${ }^{1}$ B. J. Kemp, (1983). "Old Kingdom, Middle Kingdom, and Second Intermediate Period c. 2686-1552 BC.", 136-37, In Trigger et al., Ancient Egypt: A Social History,
} 
The Egyptian Empire, founded at the beginning of the $18^{\text {th }}$ Dynasty ca. $1550 \mathrm{BC}$, experienced a lengthy period of economic growth and military success. The rapid expansion of the kingdom north into Asia and upriver into ancient Nubia began earlier when the native state was still starting its first steps towards the foundation of the first empire the world ad ever seen.

The Egyptian New Kingdom provides a wealth of information describing military conflicts with number of peoples living to the South, West and North-East of them. From the Euphrates in Western Asia to the Fifth Cataract of the Nile in modern Sudan the Egyptian army is documented as being a visible and formidable force. This active military role resulted in the endeavours of the army being at the centre of both private and royal inscriptions. The Egyptians achieved order (national security) through the prowess of the ruler, which meant that the state perpetuated grandiose images of war through royal iconography either by images or by the words. ${ }^{2}$

Warfare of this period were always described as imperial warfare, ${ }^{3}$ while the real political and economic motivations of warfare including the defence of borders, the acquisition of valuable land, livestock, natural resources and people were often masked by layers of religion and ritual which provided both moral justification and a "universal framework" for the more impious aspects of war. ${ }^{4}$ This ancient agenda is often masked further by modern analysis which has a tendency to dehumanise ancient Egyptian warfare and conflict, despite psychologists describing combat as being an integral part of human behaviour, both in ancient and modern societies. ${ }^{5}$

\section{DISCUSSION}

The records of the Early New Kingdom imperial wars, $18^{\text {th }}$ Dynasty, were initially a day by day account of activity while on campaign, which were then written as annals transposed onto the walls of the temples of Thebes to describe the brave steps to found the bases of the Egyptian Empire that

Cambridge, 71-182; D. O'Connor, (1983). "New Kingdom and Third Intermediate Period, 1552-664 BC.", 270-71, In Trigger et al. (183-278).

${ }^{2}$ S. McDermott, (2002). Ancient Egyptian Footsoldiers and their weapons: A study of military iconography and weapon remains, $\mathrm{Ph}$. D. dissertation, University of Manchester, 26.

${ }^{3}$ D. B. Redford, (1992). Egypt, Canaan and Israel in Ancient Times, Princeton, N. J.: Princeton University Press, 193.

${ }^{4}$ A.M., Gnirs, (1999). "Ancient Egypt in War and Societye in the Ancient and Medieval Worlds edited by Raaflaub, K \& Rosenstein, N. Washington: Center for Hellenic Studies, 73.

${ }^{5}$ B. Shalit, (1988). The Psychology of Conflict and Combat. New York: Praeger, 4. 
extended from the Nile Fifth cataract to the North of Syria. ${ }^{6}$ The Late New Kingdom, $19^{\text {th }}$ and early $20^{\text {th }}$ Dynasties or Ramesside Period, witnessed an important change in the way expressing royal military affairs. ${ }^{(7)}$ The kings of that period preferred the pictorial or iconographic representation with minimum chance for the textual citation, and sometimes without, of historical details which give the event its historical value and more important its reliability. ${ }^{8}$ The concern of the present paper is the attestation of the daily-life objects in the textual and pictorial sources of the New Kingdom; the researcher first investigates the occurrences of these objects then studies each item individually.

\section{The Textual narration of Daily-Life ObJects in the NeW Kingdom TeXTUAL SOURCES}

\section{ANNALS OF THUTMOSE III NARRATING HIS CAMPAIGN OF YEAR 23}

List of booty which was captured from Yenoam, Nuges, and Herenkeru:

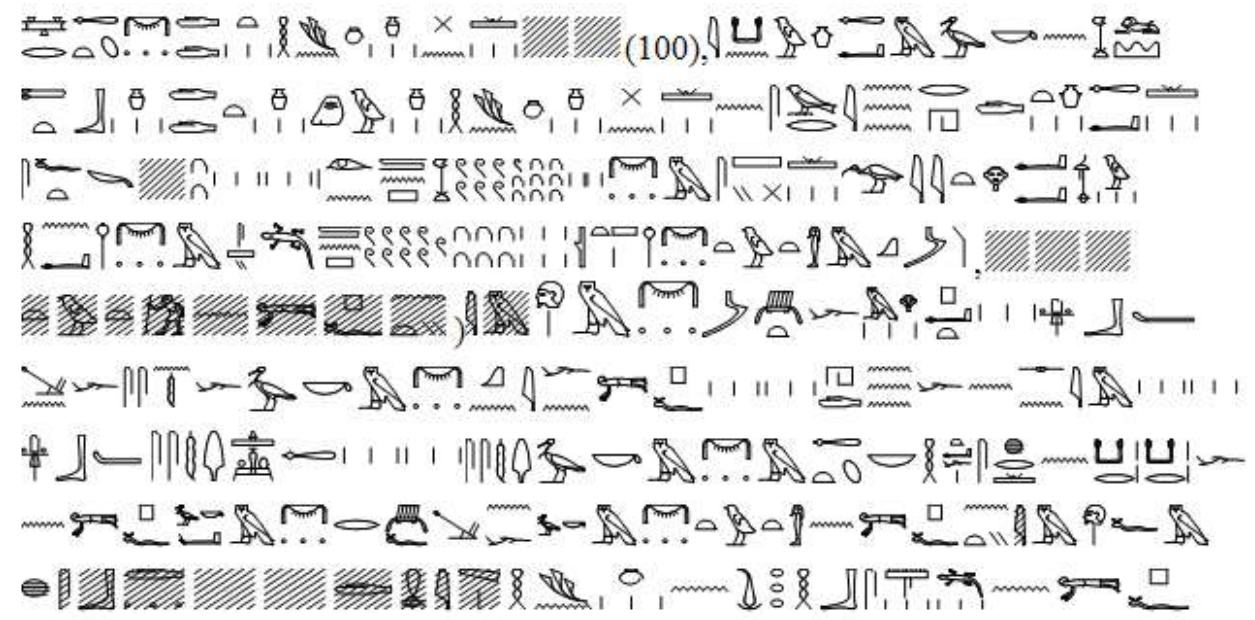

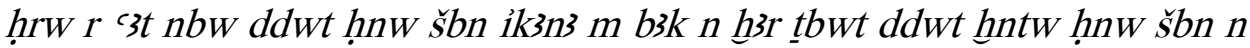
swr rhdt c $3 t$ sft $(27+\mathrm{x}) \ldots$ ir. $n$ dpn 1.784 nbw m sšy gmit hr ‘ ${ }^{\prime} y$ ḥmwt

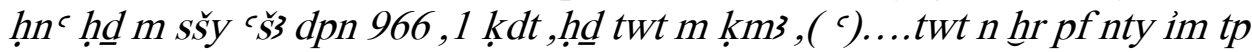
$m n b w$, m3wt $m$ hrw $p^{\varsigma} t$, 3bw, hbny ssndm b3k $m$ nbw kniwhr pf 6 ,

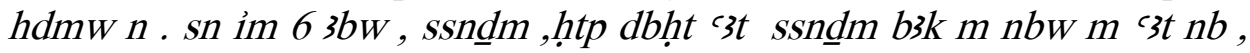

\footnotetext{
${ }^{6}$ M. Lichtheim, (1976). Ancient Egyptian literature; The New Kingdom, Berkeley: University of California Press, 29. She considers these records to be some of the more realistic found in Egypt due to their fact-based origins.

${ }^{7}$ S. Chrissanthos, (2008). Warfare in the Ancient World, From the Bronze Age to the Fall of Rome, London, xxiii

${ }^{8}$ G. A. Gaballa, (1976). Narrative in Egyptian Art, Mainz, 127-8; D. B. Redford, Egypt, Canaan and Israel, 186.
} 
ht' shr n krkr n hr pf b3k m nbw hbny, b3k m nbw twt n hr pf nty im tp .f

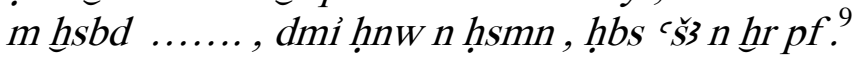

Besides flat dishes of costly stone and gold, various vessels, (100) ..., a large two handled vase akunu of the work of Kharu a Syrian city, jars, bowls, plates, various drinking vessels, large kettles, $[x]+27$ knivesmaking 1,784 deben; gold in rings, found in the hands of craftsmen, as well as silver in many rings-966 deben and 1 kidet; a silver statue in the form of ...,[a statue]—, with head of gold; the staff with human heads; carrying-chairs of that enemy: 6, of ivory, ebony, and carob-wood, worked with gold, and footstools belonging to them:6; large tables of ivory and carob-wood:6; 1 bed belonging to that enemy, of carob-wood, worked with gold and with every (kind of) costly stone, in the manner of kerker, completely worked in gold; a statue of that enemy which was there, of ebony worked with gold, its head of lapis [lazuli] $85 \mathrm{~cm} \mathrm{...;}$ Bronze vessels, and much clothing of that enemy. ${ }^{10}$

\section{ANNALS OF THUTMOSE III NARRATING HIS CAMPAIGN OF YEAR 34}

The civil items in plunder list of Campaign of year 34:

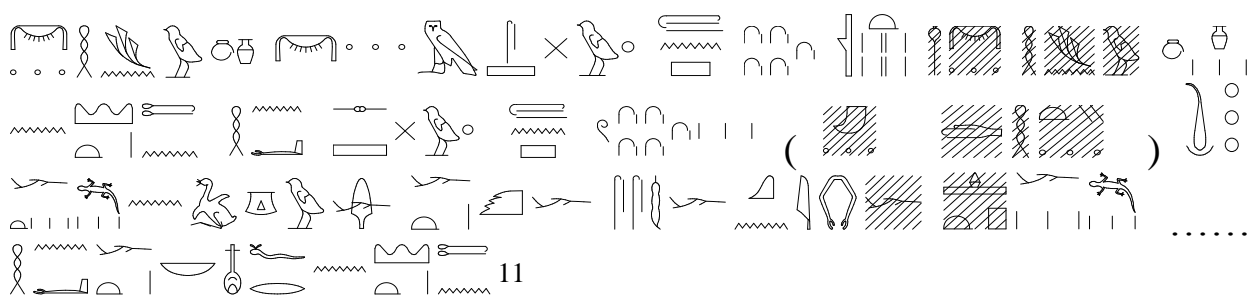

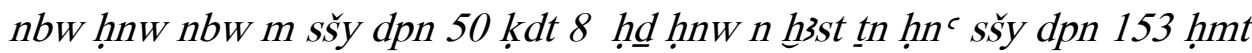

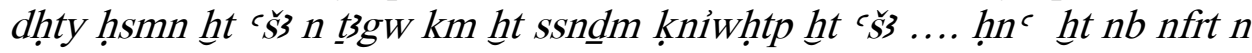
hisst th .

Golden vessels and gold in rings, 50 Deben, 8 kidet, silver vessels of this country and rings, 153 Deben; copper, lead, bronze, a quantity of thago $(t 3 g W)$ wood; many chairs of black wood (and) carob wood; together with every fine wood of this foreign country. ${ }^{12}$

\section{DaIly-life OBJects in Plunder List of Great Karnak INSCRIPTION OF MERENPTAH:}

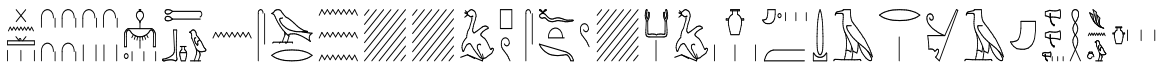

\footnotetext{
${ }^{9}$ Urk. IV, 665-667.

${ }^{10}$ BAR, II, 188; J. B. Pritchard, (1950). The Ancient Near Eastern Texts relating to the Old Testament, Princeton, $3^{\text {rd }}$ Edition, 1969, 237-238.

${ }^{11}$ Urk.IV, 704- 705.

12 D. B. Redford, (2003). The Wars in Syria and Palestine of Thutmose III, Brill, London, 79.
} 


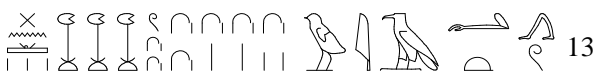

(...20 groups lost...) šbn 64 hִd tb.w n swr t3pr rhd.wt sf.wt kt .w mádrn.w

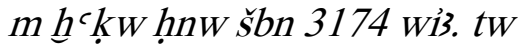

(...Lacuna...) various 64, silver drinking vessels, ( $t 3 p r)$ vessels, ( $r h d . w t)$

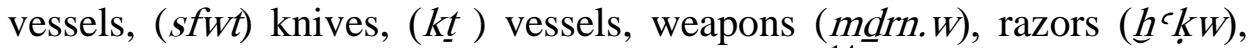
and various $(h n w)$ vessels total 3174 apart from. ${ }^{14}$ The number "3174" is including military and civil items together.

Daily-life objects in Plunder list of Heliopolis Column of MERENPTAH:

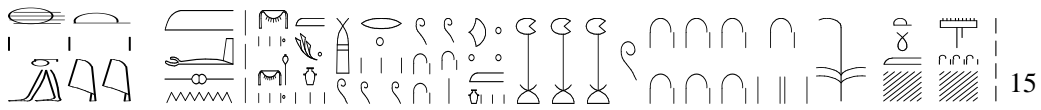

hlt ini m sn nbw ḥd $m$ ḥnw 'prw 531 ḥmt ḥnw 3174 šsrw nsw (30)4

Things brought with them: gold and silver (worked) in the shape of "hnw" vessels and jewellery: 531; metal vessels: 3174, [pieces of] royal linen $(\check{s} r W n s w):(30) 4^{.16}$

\section{The Depiction OF THE DAILy-Life OBJects IN THE NeW Kingdom Pictorial Sources}

\section{DAILy-Life OBJects OF Thutmose III's Syrian Wars at KARNAK}

As a pious and loyal king to his god, Thutmose III at his victorious return from his Syrian campaigns offered all his booty of war to his beloved god Amun in addition to other consecration gifts. ${ }^{17}$ (Fig. 1.a, b) Thutmose III chose nearest position to the Sanctuary of the Divine Bark of Amun to build what is known as Wall of Annals which nowadays is North wall around the granite sanctuary of Philip Arahedeuos. ${ }^{18}$

The Western half of the north wall around the sanctuary of Philip Arahedeuos is decorated with a fresco made of limestone in low relief. Thutmose III offers two obelisks and ten rows of his booty of war to

\footnotetext{
${ }^{13}$ KRI IV, 9.

${ }^{14}$ C. Manassa, (2003). The Great Karnak inscription of Merneptah: Grand Strategy in the $13^{\text {th }}$ Century BC, Yale Egyptological Seminar, 55-56.

${ }^{15}$ KRI IV, 38.

${ }^{16}$ H, S. K. Bakry, (1973). "The Discovery of a Temple of Merenptah at Ōn: A. Merenptah commemorates his victory over the Libyans", Aegyptus 53, 9.

${ }^{17}$ W. Wresinski, (1934). Atlas zur altägyptischen Kulturgeschichte,II, Taflen, Leipzig, tafel.33b.

${ }^{18}$ R.A. S. De Lubicz, G. DeMire, \& et al., (1999). The Temples of Karnak, Thames \& Hudson, London, 317.
} 
Amun, ${ }^{19}$ depicting the king, in heroic size, wearing the double crown, raising the sceptre, consecrating his precious offerings in front of him on behalf of Amun.

The booty of war, of all kinds, aligned on ten registers before Amun who is seated in the opposite right (East) on the top of a platform. The booty of war itself consists of various types of vessels, jars, vases with human, animal and flower ornaments, tables, chests, cases, necklaces, bracelets, sceptres, censers, silver, gold, electrum, copper, alabaster, turquoise and lapis lazuli, obelisks and mats are included. ${ }^{20}$ Mostly of these treasures made out of precious stones, the alabaster jars filled with pure unguent for the divine rituals in addition to vessels of precious stones that His Majesty made fallowing the intention of his own heart, and all other manner of objects whose number and material is specified. ${ }^{21}$

\section{DAILY-LIFE OBJECTS OF RAMESSES II'S WARS AT KARNAK}

Daily-Life objects are found as a part of Syrian spoils from Ramesses II's scene of presentation of booty of war, middle register East half, exterior South wall of Great Hypostyle Hall, Karnak Temple. These daily-life objects are arranged in 4 rows from lower to upper consisting of heaps of raw materials with an elephant tusk above it, craters with various ornaments such as rosettes and papyrus flowers; amphorae with different shapes for stoppers such as conical shape, bull's head and duck's head and others (Fig. 5). ${ }^{22}$

\section{DAILY-Life OBJECTS OF RAMESSES III'S WARS AT MEDINET HABU}

Daily-Life objects from Asiatic and Libyan campaign of Ramesses III at Medinet Habu include various shapes of vessels, amphorae, vases, craters as well as raw materials. What concerns here is the object no. 9, second row, the second from right is a necklace with panther head termination (Fig. 6). ${ }^{23}$

\section{Descriptive Study OF THE DAILy-Life ObJeCtS MENTIONED IN THE NEW KINGDOM SOURCES}

\section{FURNITURE}

After the study of texts of plunder lists, Thutmose III is the only king who carried off furniture. He brought several times remarkable pieces of

\footnotetext{
${ }^{19}$ PM II, 97.282.

${ }^{20}$ P. Barguet, (1962). Le Temple d'Amon-Rê à Karnak: Essai d'exégèse, Institut Français d'Archéologie Orientale, Le Caire, 152.

${ }^{21}$ R.A. S. De Lubicz, G. DeMire, \& et al, The Temples of Karnak, 317.

${ }^{22}$ W. Wresinski, Atlas, II, tafel.59.

${ }^{23} \mathrm{~W}$. Wresinski, Atlas, II, tafel.157
} 
furniture, definitely after the battle of Megiddo in year 23 and again in year $34 .^{24}$ These furniture items such as six large tables of offerings in ivory and carob wood, 6 footstools, 6 armchairs of ivory and carob worked with gold, ${ }^{25}$ a bed of carob -wood worked with gold and all sorts of precious stones, in the manner of the $k r k r$. The definition of "Krkr" is akkadien word which means a divan or couch. ${ }^{26}$ In all, the Syrian treasures of wood products that the Egyptians drew on the walls of their temples and their tombs include the objects usually named in the Annals of Thutmose III. Because of the natural environment to the Lebanon and Syrian cities which the slopes of Lebanon were so rich and covered with trees, so the Syrians excelled early in wood products working. ${ }^{27}$

Furthermore, there are other furniture items depicted in the scene of Thutmose III in the north wall around the Granite Sanctuary, Karnak Temple (Fig. 1.a, b), in this scene the drawings of Syrian alters or offering tables and chests can be seen. Some chests are depicted with saddle roof lid but others are depicted with a support bar. These chests were apparently dedicated for clothes, the proof of this can be found above chest's drawing is inscribed "ḥbs $n$ mnht $p d s n b w$ " that means golden chest for clothes. Another form for Syrian chests can be seen in the same scene, a chest with a decoration represented heads of serpents may be these chests specified for the temple cult. (Fig. 2) The previous chest is parallel to Tutankhamen's chest which is made in the same way. ${ }^{28}$

For Syrian Alters or offering tables there are some drawings in the previous scene for great altar in the form of a venerable block on a flat base with the usual crowning and well-groomed parapet. Perhaps the shape goes back to the battlements of Syrian city walls; Altars of the shape irregular parapet are known from Mesopotamia. In addition to another shape for offering table takes the rectangular form. Another form for offering table appeared in the previous scene, it consists of two separate parts: a round table based on a holder. This type of tables was

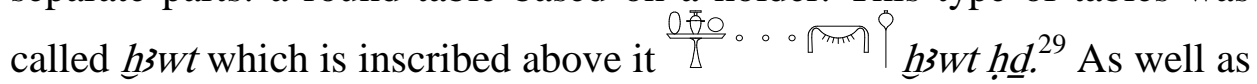
this kind of offering tables used for daily life use and, sometimes became

\footnotetext{
${ }^{24}$ W. Helck, (1962). Die Beziehungen Ägyptens Zu Vorderasien Im3 und 2 Jahratusend V. Chr, Otto Harrassowitz, Wiesbaden, 445.

${ }^{25}$ P. Montet, (1937). Les Reliques de l'Art Syrien dans l'egypte du Nouvel Empire, Paris, 72.

${ }^{26}$ J. E. Hoch, (1994). Semitic Words in Egyptian Texts of the New Kingdom and Third Intermediate Period, Princeton University Press, no.486.

${ }^{27}$ P. Montet, Les Reliques de l'Art Syrien, 72.

${ }^{28}$ S.Taufik, (1969). "Eine KleineListe von Weihgeschenken Thutmosis III fur Amon in Karnak", MDAIK 25, 180.

${ }^{29}$ W. Wresinski, Atlas, II, tafel. 33b.
} 
apart for funerary furniture. (Fig.3) The function of this table continued as a bearer of offerings of various types of food until the end of the Pharaonic era, despite the change in its shape from a round tray to a rectangular. It is worth mentioning that the offering table of the gods was also called $h 3 w t^{30}$

\section{JEWELLERY}

The valuable nature of the materials used in jewellery makes it an essential target for being looted by Egyptian warriors. ${ }^{31}$ Jewellery $"{ }^{\prime c} p r w^{\prime{ }^{32}}$ was brought as booty as mentioned in Plunder List of Merenptah $^{33}$ as well as it repeated many times in Annals of Thutmose III as the wives of the rulers of Kadesh, which are taken as captives, brought their jewellery with them and all their possessions were taken as booty. The jewellery of the wives of enemy was used in beautifying the sacred bark of Amun. ${ }^{34}$ Moreover there are some depictions of necklaces and bracelets in spoils scene of Thutmose III on the Wall of Annals, around the Granite Sanctuary. The inscription besides the drawings of these necklaces and bracelets confirmed that they are worn by the god upon the divine limbs when he appears in procession. ${ }^{35}$ The forms of Necklaces or neck collars are depicted with many shapes, as one of these shapes consists of three rows of beads, may be the beads made of gold, silver and other precious stones no.(81), the other forms with 3 cords of pearl closed with ribbons nos.(87and 88). Bracelets are made of metal sheet with two straps nos. (82-85). (Fig. 4) Hence there is a representation of collar with head of panther in spoils scene of Ramesses III (Fig. 6). ${ }^{36}$

\section{Clothes}

Clothes 8 \& $\int_{1}$ of Thutmose III. Unfortunately the Annals did not offer any details about material, shapes or kinds of the mentioned clothes. ${ }^{37}$

As well as, the royal linen plundered from the Tjemehu was over "34 "clothes ( $h b s)$ of the finest quality linen $\check{S} s r W n s W$, as recorded on the

${ }^{30}$ M. M. F. Mostafa, (1982). Untersuchungen Zu Opfertaflen im Alten Reich, Gerstenberg Verlage, Hildesheim, 77.

${ }^{31}$ Z. Bahrani, (1995). "Jewelry and personal arts in Ancient Western Asia." CANE III, 1635.

${ }^{32} \mathrm{~Wb}$ I, 181.2-4.

${ }^{33}$ KRI IV, 38.

${ }^{35}$ BAR II, 219.

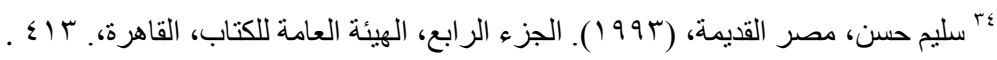

${ }^{36}$ P. Montet, Les Reliques de l'Art Syrien, 44.

${ }^{37}$ W. Helck, (1962). Die Beziehungen Ägyptens Zu Vorderasien Im 3 und 2 Jahratusend V. Chr., Otto Harrassowitz, Wiesbaden, 436. 
Heliopolis 'Victory Column'. The mantles or robes of the Tjemehu are usually thought to be of painted and decorated leather and the kilts sometimes worn by the Tjemehu are presumably of the same material they may be display the same range of colours. The existence of linen suggests that some at least wore clothes of this material. ${ }^{38}$ Moreover the fine linen referred to in the plunder lists of Merenptah may be were taken from Tjemhu already active in Egyptian territory, then may have been, in turn, plundered from the Egyptians by Tjemehu raiders, but certain data suggest this is not a fully satisfactory explanation. ${ }^{39}$

\section{Plates}

They are two types of plates occurred in the booty of war scenes; first, it takes the shape of semi-circular based on foot which appeared in the booty scenes of Ramesses II. Second type, it takes the shape of flat dish. Above it, a head of animal was placed on these plates as head of bull. ${ }^{40}$ In addition to these animals heads resemble rytons which consist of a horn ending with a head of animal as lion, grey hound, and griffin and so on; rytons may be used as cups for drinking. There are many various forms of these rytons in spoils scenes of Thutmose III and Ramesses III (Figs. 6, 7). ${ }^{41}$

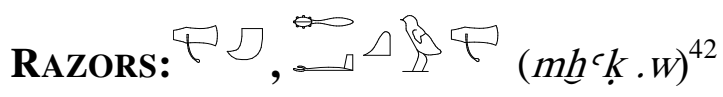

$m \underline{h} \subset \underline{k}$ means 'razor', since sometimes it is identified by the sign

37), which represents the characteristic Egyptian razor of the New Kingdom, while in other instances the sign is used as determinative. The name of the object, moreover, is consisting of the formative prefix $\mathrm{m}$ and the verb $\underline{h} c k$ 'to shave'. Razors were made of copper or bronze, the handle, which was made separately, being usually of the same material, though sometimes of wood. ${ }^{43}$

Only two types of razor are commonly known from the New Kingdom. The first consists of a broad, oblong blade of thin metal, provided with a curved wooden or metal handle attached by means of rivets to the side of the blade. The second type is a slender, knife-like implement, made entirely of metal, with a slanting, slightly curved edge at its upper end,

\footnotetext{
${ }^{38}$ D. O'Connor, (1990). "The Nature of Tjemhu (Libyan) Society in the Later New Kingdom”, In A. Leahy (ed.), Libya and Egypt c. 1300-750 B.C., London, 63.

${ }^{39}$ D. O'Connor, "The Nature of Tjemhu (Libyan) Society", 101.

${ }^{40}$ W. Wresinski, Atlas, II, tafel. 33b, tafel. 157.

${ }^{41}$ P. Montet, (1931). "L'art Syrien vu par les Égyptiens du Nouvel Empire", BIFAO 30, 781-782; W. Wresinski, Atlas,II, tafel.157.

${ }^{42}$ G. Andreu \& S. Cauvill, (1978) "Vocbulaire Absent du Wortetbuch (II)", RdE 30, 17.

${ }^{43}$ J. Janssen, (1975). Commodity Prices from the Ramesside Period, Brill, Leiden, 299.
} 
and a secondary, chisel-like edge at its butt (Fig. 8). There can be little doubt that the first type is that termed $m h c^{k}$ in the New Kingdom, since it is this form of razor which invariably occurs either as a determinative or ideogram in writings of the word $m h^{c} k_{.}^{44}$

Razors only found in the plunder list of Merenptah. The Tjemehu are bearded, but the beards are not full (i.e. part of the face was shaved or plucked) and heads sometimes appear to have been partially shaved. ${ }^{45}$

\section{KNIVES $\lceil\stackrel{x}{\Sigma} s \boldsymbol{f}$. $\boldsymbol{w} \boldsymbol{t}$}

Knives mean $s f$.wt which was brought as booty of war in the Annals of year 23 campaign of Thutmose III and Year 5 Libyan Battle of Merenptah. ${ }^{46}$ The word "sft", is known from the Middle Kingdom, refers to both 'knife' and a 'sword', As for what type of knife may be indicated, the sf.t is probably the butcher's or kitchen knife with one sharpened edge, while the " $w p$ "is perhaps the double-edged knife. Furthermore, the name $s f t$ is derived from the verb to slaughter, and slaughtering seems as a rule to have been done with such a single-edged knife and "sft" seems to belong to the kitchen. ${ }^{47}$ From the New Kingdom, knives are made out of metal unlike before new kingdom made out of stone. ${ }^{48}$

\section{STATUES}

Statues of the foe are considered one of the items which were existed once in New Kingdom military sources in the Plunder List of Thutmose III's campaign of year 23. These statues one of them is about $1.75 \mathrm{~cm}$ and the other is about $85 \mathrm{~cm}$. They are made of ebony inlaid with god, their heads from lapis lazuli. Unfortunately the description of two statues is not enough clear, except they attributed to the enemy without any details. ${ }^{49}$

Montet suggested that according to plunder texts the Egyptians seem to have preferred the statues which inlaid with precious metal deserve to take to Egypt than stone statues. Moreover ebony is a too valuable type of wood which covered by sheets of gold. ${ }^{50}$ In all likelihood the character's body was made of wood, his clothes and jewellery from gold. It can be

\footnotetext{
${ }^{44}$ W.V. Davies, (1977). "Tut'ankhamun's Razor-Box: A Problem in Lexicography", JEA 63, 110 .

${ }^{45}$ D. O'Connor, "The Nature of Tjemhu (Libyan) Society", 62.

${ }^{46}$ Urk IV, 666; KRI IV, 9.

${ }^{47}$ J. Janssen, Commodity Prices from the Ramesside Period, 324.

48 A.B. Liyod, (2014). Ancient Egypt: State and Society, Oxford University Press, London, 119.

${ }^{49}$ BAR II, 188.

${ }^{50}$ P. Montet, Les Reliques de l'Art Syrien, 70.
} 
concluded that the inlaying method of statues is known in Syria like Egypt.

\section{CONCLUSIONS}

- New Kingdom military sources provided an important data about the daily-life objects of the foreign enemies that their style of life can be traced through these narratives describing their possessions being captured by the Egyptian king who now celebrates his victory and commemorates it by recording the details of objects he captured.

- The daily-life or civil items varied, as mentioned in the texts or depicted in the scenes, from pieces of furniture, jewellery, plates, to clothes and saving razors.

- The extant textual and pictorial sources of the New Kingdom Period suggest that Egypt maintained intense military supremacy over its neighbours; the matter which reflected in the kinds, number and amount of items of the booty of war.

- The different occurrences of such daily- life civil objects in the context of the booty of war represent a strong evidence to the thorny subject of the City Assault aftermath the achievement of the victory not only the destruction and seizure of the enemies' camps.

- It is apparent from the scenes of the booty of war that the final destination of these items as well as other objects which were captured in the battlefield was the treasuries of the Amun temple at Karnak. Moreover, raw materials and metal are found their way to pharaoh's carpentry workshops as they were essential for producing lavish items of furniture, as well as metals from which tools, weapons, household utensils and luxury wares were made.

- The only king who carried off furniture as booty is Thutmose III. He brought several times remarkable pieces of furniture, definitely after the Battle of Megiddo in year 23 and again in year 34 .

- Razors are only found in the plunder list of Merenptah, made out of metal.

- The various occurrences of such daily-life objects in the context of booty of war, either textual or iconographical, confirmed that the main cause of campaigns is expansionist rather than economic. 


\section{REFERENCES}

Andreu G., Cauvill, S., (1978). "Vocbulaire Absent du Wortetbuch (II)", RdE 30, 10- 21.

Bahrani, Z., (1995). "Jewelry and personal arts in Ancient Western Asia." CANE III, 1635- 1646.

Bakry, H, S. K., (1973). "The Discovery of a Temple of Merenptah at Ōn: A. Merenptah commemorates his victory over the Libyans", Aegyptus 53, 3- 21.

BAR= Breasted, H., (1906). Ancient Records of Egypt, Russell \& Russell, New York.

Barguet, P., (1962). Le Temple d'Amon-Rê à Karnak: Essai d'exégèse, Institut Français d'Archéologie Orientale, Le Caire.

Bell, L., (2007). "Conflict and Reconciliation in the Ancient Middle East: The Clash of Egyptian and Hittite Chariots in Syria, and the World's First Peace Treaty between "Superpowers", in Raaflaub, K. A. (ed.), War and Peace in the Ancient World, U.K., Blackwell Publishing Ltd., 98- 120.

Chrissanthos, S., (2008). Warfare in the Ancient World, From the Bronze Age to the Fall of Rome, London.

Davies, W.V., (1977). "Tut'ankhamun's Razor-Box: A Problem in Lexicography", JEA 63, 107-111.

De Lubicz, R.A. S., (1999). DeMire, G., \& et al, The Temples of Karnak, Thames \& Hudson, London.

Gaballa, G. A., (1976). Narrative in Egyptian Art, Mainz.

Gnirs, A.M. (1999). "Ancient Egypt in War and Society" in the Ancient and Medieval Worlds (edi.) by Raaflaub, K\& Rosenstein, $\mathrm{N}$. Washington: Center for Hellenic Studies, 73, 71-104.

Helck, W., (1962). Die Beziehungen Ägyptens Zu Vorderasien Im3 und 2 Jahratusend V. Chr, Otto Harrassowitz, Wiesbaden.

Hoch, J. E., (1994). Semitic Words in Egyptian Texts of the New Kingdom and Third Intermediate Period, Princeton University Press.

Janssen, J., (1975). Commodity Prices from the Ramesside Period, Brill, Leiden.

Kemp, B. J., (1983). "Old Kingdom, Middle Kingdom, and Second Intermediate Period c. 2686-1552 BC.", 136-37, In Trigger et al., Ancient Egypt: A Social History, Cambridge, 71-182.

KRI= Kitchen, K. A., (1969-1990). Ramesside Inscriptions, Historical and Biographical, 8 vols. Oxford: Blackwell.

Lichtheim, M., (1976). Ancient Egyptian literature, Volume II, The New Kingdom, Berkeley: University of California Press.

Liyod, A.B., (2014). Ancient Egypt: State and Society, Oxford University Press, London. 
Manassa, C., (2003). The Great Karnak Inscription of Merneptah: Grand Strategy in the 13th Century BC, Yale Egyptological Seminar.

McDermott, S., (2002). Ancient Egyptian Footsoldiers and their Weapons. A Study of Military Iconography and Weapon Remains, Manchester: Unpublished $\mathrm{PhD}$ thesis.

Montet, P., (1937). Les Reliques de l'Art Syrien dans l'egypte du Nouvel Empire, Paris.

Montet, P., (1931). "L'art Syrien vu par les Égyptiens du Nouvel Empire", BIFAO 30, 781-782.

Mostafa, M. M. F., (1982). Untersuchungen Zu Opfertaflen im Alten Reich, Gerstenberg Verlage, Hildesheim.

O'Connor, D., (1990). "The Nature of Tjemhu (Libyan) Society in the Later New Kingdom", In A. Leahy (ed.), Libya and Egypt c. 1300750 B.C., London, 29-114.

O'Connor, D., (1983). "New Kingdom and third intermediate period, 1552- 664 BC.", in B.G. Trigger, B.J. Kemp et al. (eds.), Ancient Egypt: A social history, Cambridge University press.

P. M= Porter B. and R. Moss, (1927). Topographical Bibliography of Ancient Egyptian Hieroglyphic Texts, Relief and Paintings. Oxford.

Pritchard, J. B., (1969). The Ancient Near Eastern Texts relating to the Old Testament, Princeton, 1950, 3rd Edition.

Redford, D. B., (2003). The Wars in Syria and Palestine of Thutmose III, Brill, London.

Redford, D.B. (1992). Egypt and Canaan in the New Kingdom. BeerSheva: Ben-Gurion University of the Negev Press.

Shalit, B., (1988). The Psychology of Conflict and Combat. New York: Praeger.

Taufik, S., (1969). "Eine KleineListe von Weihgeschenken Thutmosis III fur Amon in Karnak", MDAIK 25, 179-183.

Urk. IV= Helck, W., (1961). Urkunden der 18. Dynastie. Übersetzung zu den Heften 17-22. Bearbeitet und übersetzt, Berlin.

Wb.= Erman A. and Grapow, H., (ed.), (1926- 1953). Worterbuch der Aegyptischen Sprache. Berlin.

Wresinski, W. (1934). Atlas zur Altägyptischen Kulturgeschichte, II, Taflen, Leipzig.

سليم حسن، مصر القديمة، (ب99 (1). الجزء الرابع، الهيئة العامة للكتاب، القاهرة. 


\section{FiguRES}

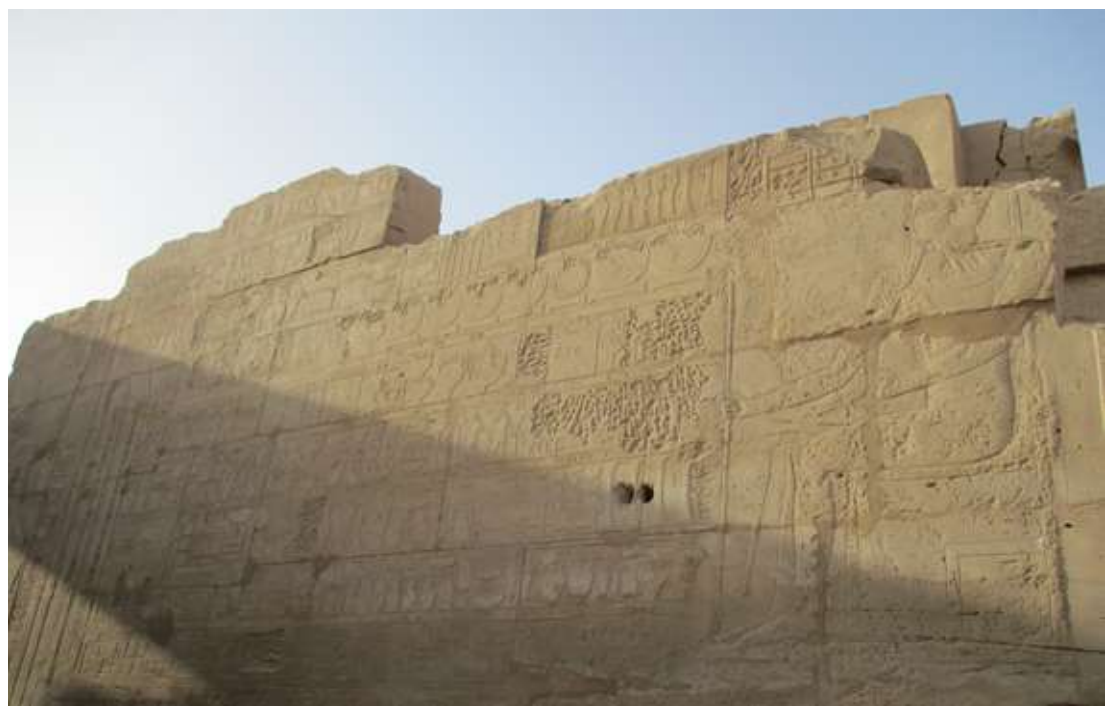

Fig. 1.a Thutmose III presenting his booty of war to god Amun (By researcher)

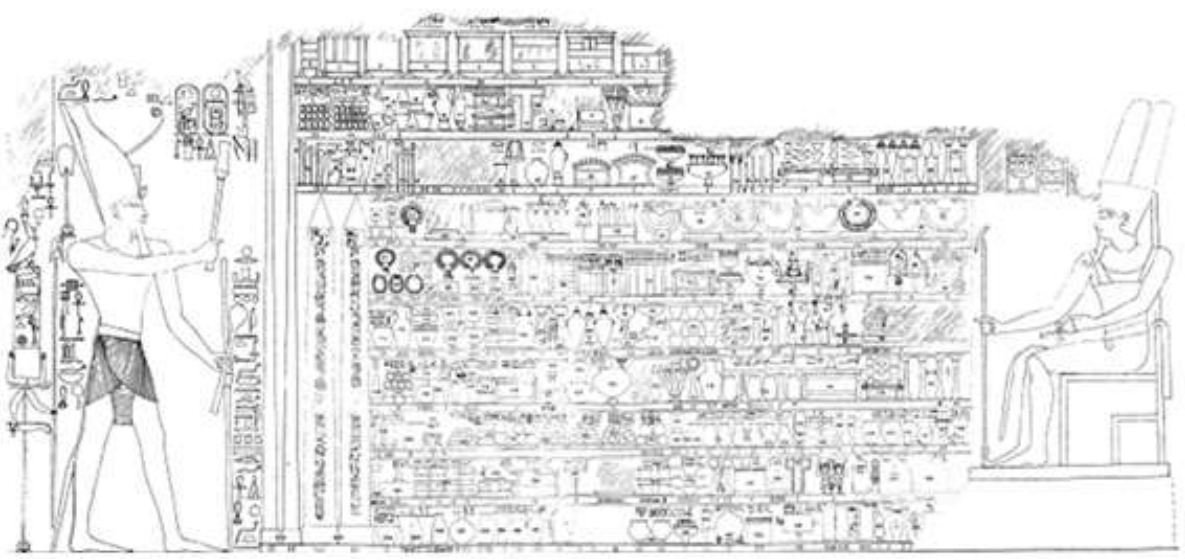

Fig. 1.b Thutmose III presenting his booty of war to god Amun

W. Wresinski, Atlas zur altägyptischen Kulturgeschichte, II, Taflen, Leipzig, 1934, tafel. 33b 

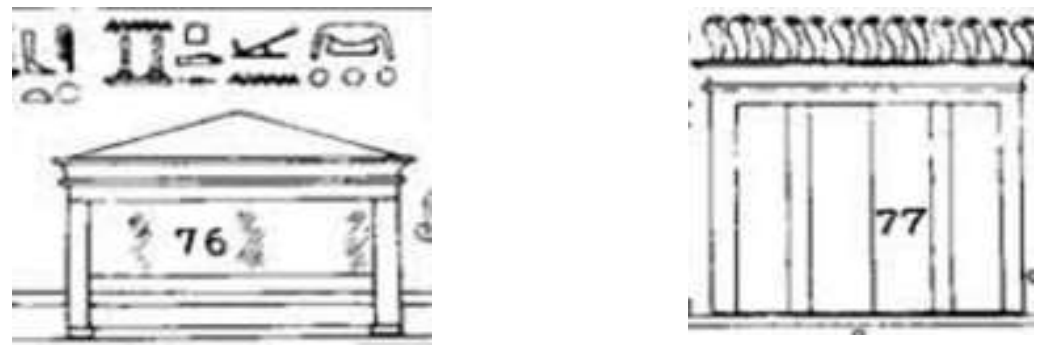

Fig. 2 Details of chests from the scene of Thutmose III presenting his booty of war to god Amun, Wall of Annals, Karnak

W. Wresinski, Atlas, II, tafel. 33b .nos.76-77

("Note. The objects are numbered by Wresinski from top to bottom, right to left)

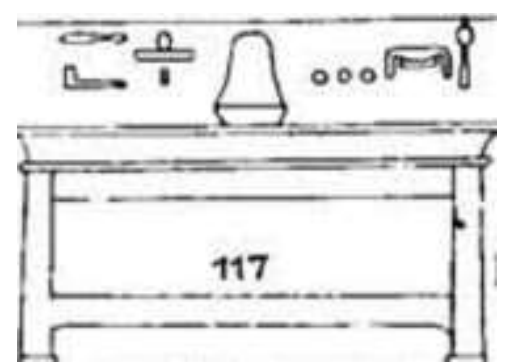

no. 117 Altar of Rectangular shape $\Leftrightarrow$ \& o.

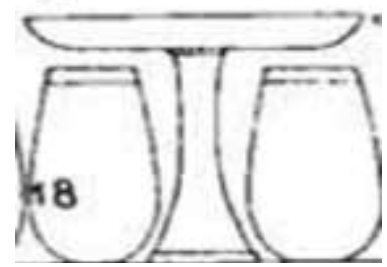

Fig. 3 Details of Alters from the scene of Thutmose III presenting his booty of war to god Amun, Wall of Annals, Karnak

W. Wresinski, Atlas, II, tafel. 33b no.117, 118,177.

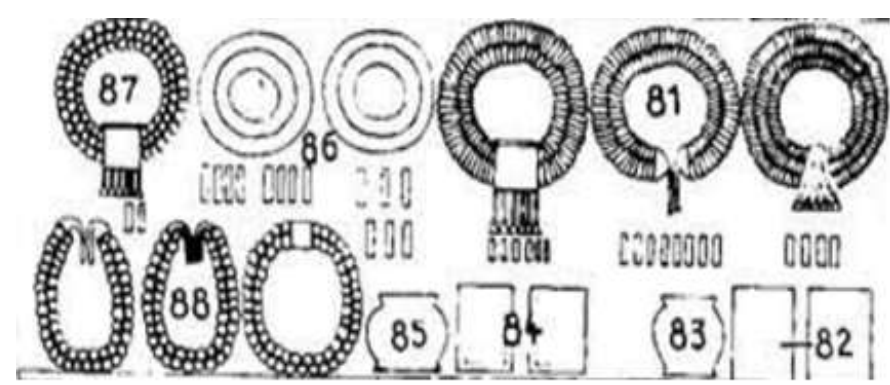

Fig. 4 Bracelets and Necklaces in scene of Tuthmosis III presenting his booty of war to god Amun, Wall of Annals, Karnak

W. Wresinski, Atlas, II, 33b, nos. 81-88. 

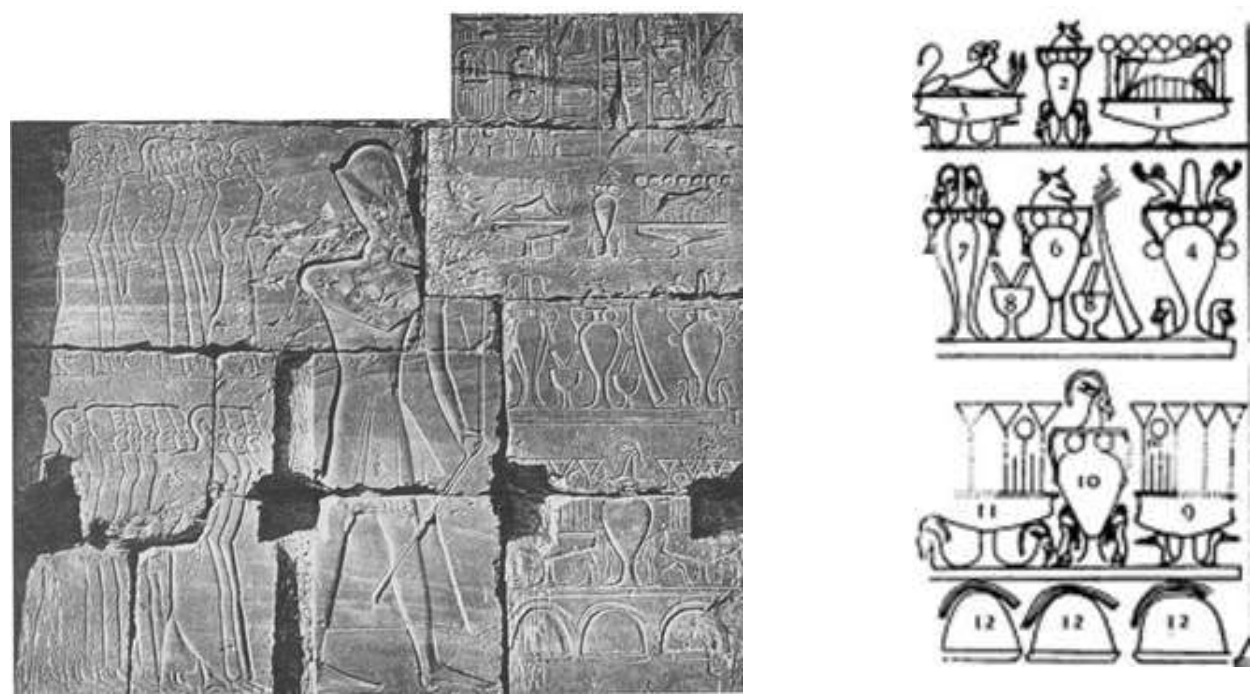

Fig. 5 Daily-Life Objects of Ramesses II at Karnak W. Wresinski, Atlas, II, tafel.59.

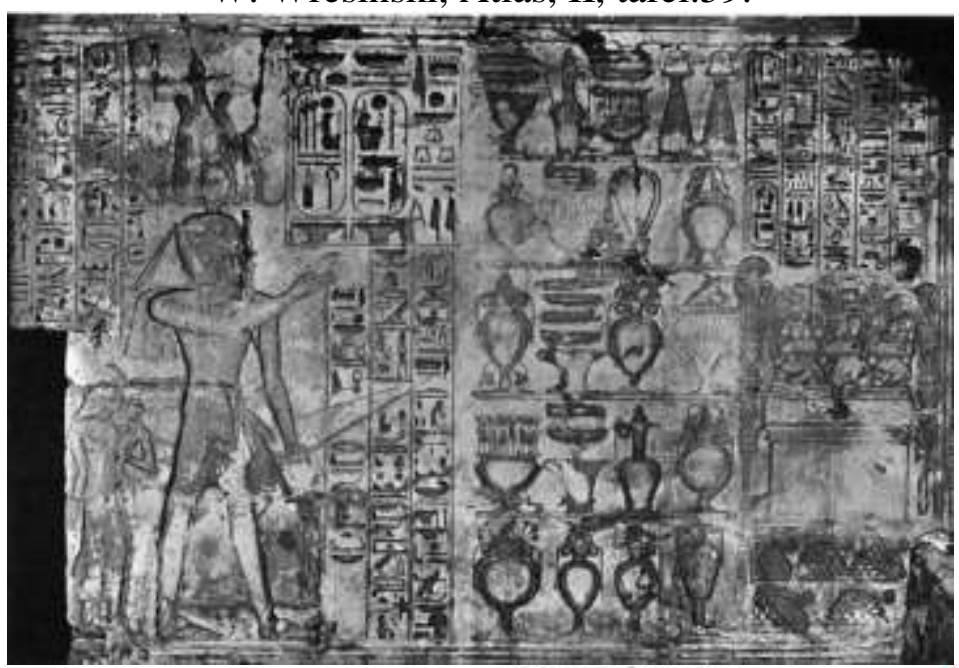

Fig. 6 Daily-Life Objects among Asiatic and Libyan booty of war of Ramesses III at Medinet

Habu (below: detailed view of the necklace)

W. Wresinski, Atlas, II, tafel.157.
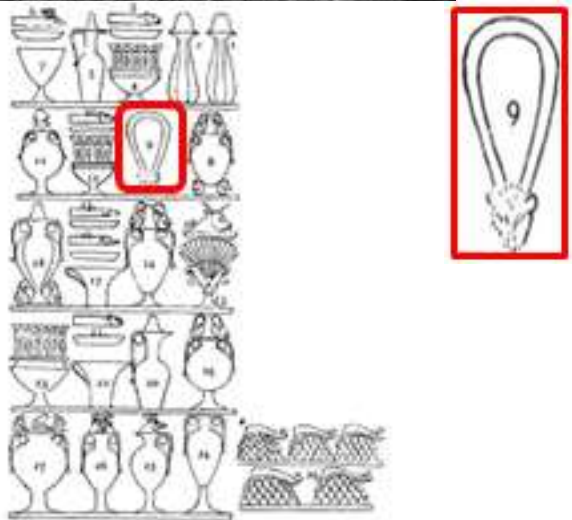


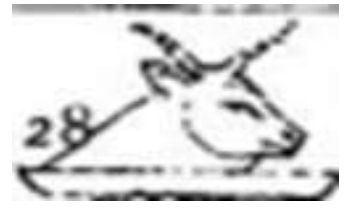

Flat dish

Ramesses III at Medinet Habu

W. Wresinski, Atlas, 157, no.28.

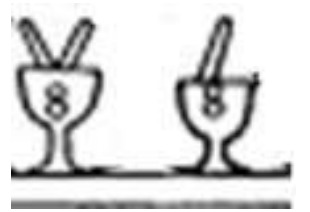

Semicircular based on foot

Ramesses II at Karnak W. Wresinski, Atlas, II, tafel.59, no.8.
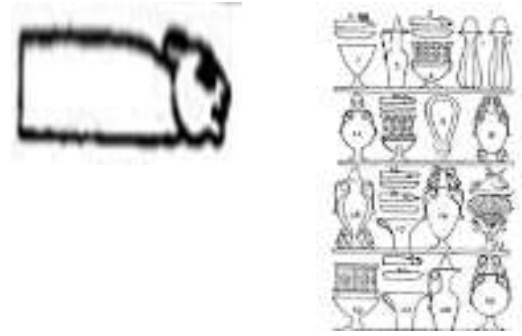

(ryton) repeated 4 times in the middle of each register

Ramesses III at Medinet Habu W. Wresinski, Atlas, II, tafel.157.nos. 3, 10, 15,16, 21

Fig. 7 Foreign Plates from scenes of booty of war of Thutmose III W. Wresinski, Atlas, 33b, 157

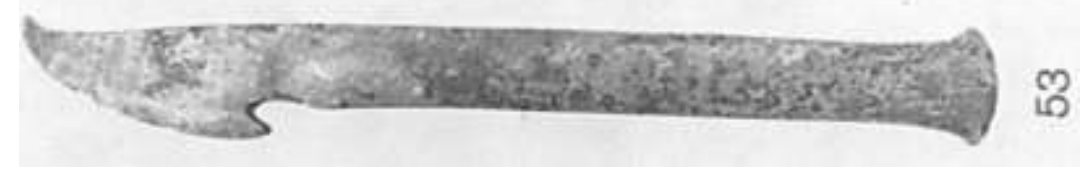

Fig. 8 Razor of Tutankhamen found in the annex of the tomb and now in the Griffith Institute, Oxford

W.V. Davies, Tutankhamen's Razor-Box: A Problem in Lexicography, JEA 63 (1977), [107- 111], pl. XVIII. 2. 